\title{
The Infiniscience of the hospitable God of Abraham, Isaac and Jacob: Re-interpreting Trinity in the light of the Rublev icon
}

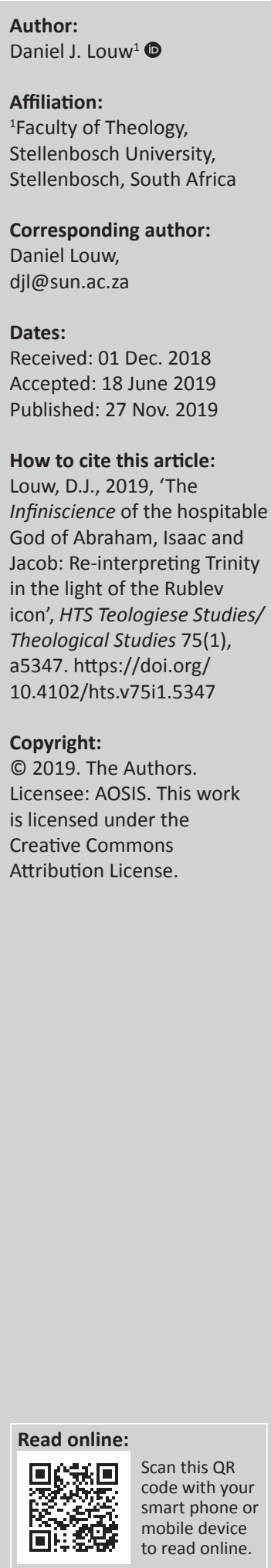

Because of the impact of church doctrine and many documents explaining the official confession of many denominations in Christianity, Trinity was mostly defined in terms of static and substantial categories (the impassibility of God). The undergirding research assumption is that the latter reflects, in most cases, more abstract and rather positivistic metaphysical speculation than representing the vividness of God's compassionate being-with as explained and revealed in the narratives of the biblical account on God's graceful intervention with the frailty of human life. The relational dynamics between the Father, the Son and the Spirit should be revisited. In this respect, the Rublev icon on Trinity could help establish the circular and spiral thinking of divine perichoresis as modes of God's unpredictable, but faithful, covenantal and redemptive encounter with human misery. Trinitarian thinking should be directed by hospice-categories rather than by personhood-categories representing 'substance'. It is argued that the trinitarian interplay should be re-interpreted in terms of compassionate categories stemming from the passio Dei in theopaschitic theology. This approach should be supplemented by the bowel categories of ta splanchna in order to qualify the infiniscience of the JHWH-Godhead: the being of divine interventions in terms of verbing terminology.

Keywords: Trinity; Perichoresis; Rublev Icon; Infiniscience of God; Verbing God; Fides Quaerens Beatitudinem; Theopaschitic Theology.

\section{Introduction}

In 1967, I was forced to write an examination on the characteristics of God. I was forced to study divine characteristics. Some were knowledgeable and accessible to the human mind and thus communicable. Others were non-knowledgeable and could not be defined and understood as such. ${ }^{1}$ I was deeply puzzled and confused. I made sure that I remembered all the 'undefinable characteristics' and averaged $87 \%$.

However, 'God' became an exercise of the human mind, and I lost my awe for the unfathomable mystery of divine intervention. But then, in 2013, I embarked on a study in iconography (Louw 2014) and came across the relational dynamics of the encircling and hospitable depiction of the Godhead in the Rublev icon - a kind of divine perichoresis as the Father, the Son and the Holy Spirit focussed on the chalice. The attention is on compassionate hospitality and not on metaphysical speculation regarding the essence of Trinity.

To my mind, God became suddenly 'word-able' and 'approachable', a kind of vivid infiniscience of God.

In his book on Trinity, Moltmann (1980:25) points out the necessity to re-interpret the categories employed by systematic theology and many ecclesial confessions of faith to describe the dynamics of the Divine Entity: On 'being God'. In the 20th century, it became clear that meta- and omnicategories are not any more appropriate to articulate the 'presencing' of God. What is most needed is the challenge as to how to deal with multidimensionality. This challenge turns to the different encountering narratives in the biblical account regarding the multifaceted countenance (visage) of God. The Godhead was most often defined in terms of strict ontic categories and very prescriptive dogmatic characteristics - God as a supreme being ${ }^{2}$ rather than applying abstract definitions

2.For example, Article 11 in the Canon of Dordt professes: 'And as God Himself is most wise, unchangeable, omniscient, and omnipotent, so the election made by him can neither be interrupted nor changed, recalled, or annulled; neither can the elect be cast away, nor their number mislead' (Psalter 1959:40)

Note: The collection entitled 'God as One', sub-edited by Erna Oliver (University of South Africa) and Willem Oliver (University of South Africa). 
about the very being of God and the so-called divine characteristics like the omnipotence and omniscience of God; that is, language that describes God's 'what' (essential and substantial categories defining an ontology of Being) - the challenge within the networking paradigms of contemporary global and functional thinking is to attend to the 'how' of God (God's presencing and being there where humans are).

The term 'presencing's stands for a kind of encounter wherein the past, the present and the future intersect in such a way that sensing (experience) and present moment (state of being) coincide in order to create a sense of meaningfulness and purposefulness. The point in using 'presencing', rather than merely 'presence of God', is that God's being-there is now described in terms of existential networking and relational categories, that is, categories by which human beings express their acknowledgment of the fact that God's faithfulness is penetrating not merely their mind but also all the dimensions of the being functions. Even sensuality is part and parcel of the 'how of God' in the happenstances of life. For people that trust God and reflect on the meaning of daily happenstances (teleological reflection, a hermeneutics of purposefulness), the awareness of the diversity and richness of divine interventions coincide in such a way that a linear understanding of time makes place for circularity and a spiral interpretation.

Presencing is about the 'opening of the human mind' (significant reflection) and the 'opening of the heart' (wisdom) as well as a new understanding of God, not anymore in terms of fixed substantial categories or rational causative explanations, but in terms of the experiential categories of existential dynamics. The latter refers to open, unfinished, incomplete growth categories that operate within the paradigmatic framework of hope and adventus categories. With adventus is then meant the coming of God through the how of compassionate being-there where humans suffer. It expresses the notion of 'the living God' in terms of diaconic outreach, charity, comfort (paracletic being-there) and marturia (witnessing the gospel). Instead of the traditional missio Dei, the emphasis is on the passio Dei. Thus, the emphasis on theopaschitic thinking rather than metaphysical thinking. It further implies a paradigm shift from analytical causative thinking to integrative circular thinking. In Old Testament thinking, presencing refers to the notion of fellowship with God - coram Deo, which forms the backbone of the principle of koinonia, namely, that worship and celebration in ecclesial thinking is a representation of the divine sacrificial act of forgiveness, reconciliation and mediatory love (replacement) within the quality of graceful interaction between human beings.

3.For the use of the concept 'presencing', see its meaning within the parameters of the interplay between a pastoral, psychological and spiritual approach in coaching; '...presencing shifts the place of perception to the source of an emerging future ...presencing shifts the place of perception to the source of an emerging future whole - to a future possibility that is seeking to emerge. (Kempen 2015:140). 'Presencing is a blended word combining sensing (feeling the future possibility) and presence (the state of being in the present moment) (Kempen 2015:140). 'The boundaries between three types of presence collapse: the presence of the past (current field), the presence of the future (the emerging field of the future), and the presence of one's authentic Self. When this co-presence, or merging of the three types of presence, begins to resonate, we experience a profound shift, a change of the place from which we operate' (Kempen 2015:140-141).
The challenge to shift from causative thinking to circular thinking, from metaphysical and substantial thinking to systemic relational thinking, creates the following research question: If presencing is about the dynamics of God's beingthere and being-with (Hall 1993) within the realm of the happenstances of life, the experience of the senses and the occurrence of existential events of pain and suffering, how could the dynamics of God the Father, God the Son and God the Holy Spirit be reframed so that Trinity is not understood as a fixed status of static entities but as dynamic positions within the divine engagement with the trajectories of life?

With reference to the research problem, the research assumption is that in the re-interpretation of Trinity, a praxis approach to theological reflection should move from a hermeneutics of metaphysical speculation (ontological interpretation), with the danger of a so-called abstract, fixed and even exclusive inter-trinitarian dynamics between God the Father, God the Son and God the Holy spirit (defined by omni-categories), to an inclusive, encircling and embracing 'being-there-where-they-are'; to a kind of 'economics of grace' defined by verbing categories and relational paradigms (the outcome of salvation as enfleshed in the renewal and transformation of being and human relationships) (Berkhof 1973). Within a systems approach, the option available is networking thinking with the emphasis on position and attitude rather than on substance and essence.

God is explained less in terms of character-definitions (hoedanigheid) and more in terms of active intervening infinitions (hoe-doenighede). Thus, the challenge to apply theopaschitic categories to trinitarian thinking.

\section{From impassibility to passion in praxis thinking}

With impassibility is meant the notion that the divine Godhead functions independent of any human influence and cannot be described in terms of any emotional reaction or experience of pain or any other human infliction. Divine aseity is rendered as totally removed from any other being. God is wholly independent and in no way casually dependent. To think of God in terms of passion categories was in fact a kind of blasphemy.

In Greek thinking, it was Xenophanes who warned against the tendency to attribute to the gods what is shameful to human beings. He therefore attacked the popular religious notions of the Greeks with a view to founding a purer and nobler conception of Deity (Stace 1960:41). A kind of wandering God, moving about from place to place (beingthere), was totally absurd. Suffering and compassion were not attributes that could be ascribed to a divine entity.

In the Christian tradition, systematic reflection on Trinity (doctrine on Trinity) portrayed God mostly in terms of the more static categories of an ultimate Substance, or absolute Subject (the impassibility of God) (Moltmann 1980). 
Since early times of the Christian understanding of Trinity, trinitarian thinking made use of substantial and ontological categories. God was therefore described in terms of a divine substance: Una substantia - tres personae. God is One and homogeneous. Simultaneously, God is constituted and differentiated by three individual, divine persons. The three persons are differentiated from one another, but in essence, they are one within the common, divine Substance (Moltmann 1980:31-32).

The influence of the Aufklärung (Enlightenment) on theological thinking was a paradigmatic shift away from metaphysical principles (arché-categories) to rational categories shaped by positivistic terminology correlating with subjectivity: A hermeneutics of mindful, rational personalities and analytical reflection.

Thus, the emphasis that God should be addressed in personal categories (Moltmann 1980:31). Subjectivity and personhood became the categories to reframe a static Godhead as projected by Hellenistic thinking.

Static and substantial categories were used to probe the mystery of the triadic interconnectedness of the divine.

In the Heidelberg Catechism, it is postulated that Christ is true man and true God. With respect to his human nature, he is no more on earth; but with respect to his Godhead, majesty and Spirit, he is at no time absent from us (Psalter 1959:29). A careful analysis of this kind of formulation makes one aware of the impact of Platonic dualism in metaphysical thinking, that is, probing into the ontic substance of a divine and transcendent entity. The implied tension between the divine dimension and the human dimension causes an ontic split with the intriguing question as to how faith can maintain the unity of God. Question 48 poses the following dilemma (Psalter 1959):

But if his human nature is not present wherever his Godhead is, are not then these two natures in Christ separated from one another? The answer: Not at all; for since the Godhead is illimitable and omnipresent, it must follow that it is beyond the bounds of the human nature it has assumed, and yet none the less is in this human nature and remains personally united to it. (p. 29)

The category of personhood is introduced to bring about a kind of 'psychological' and 'rational' interconnectedness and to maintain a superficial kind of ontic monophysitism. ${ }^{4}$ Within this very positivistic and rationalistic paradigm, there was no place for the notion of passio Dei.

The notion of divine compassion and its link to suffering was picked up by Küng in his book Menschwerdung Gottes (1970). He posed the very intriguing question: Can God suffer and

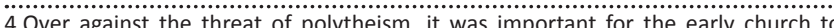
. not to 'frees' the Godhes in the Godhead. At the same time, it was important not to 'freez' the Godhead into static categories. The notion of "monophysitism" wanted to assert that in the person of Jesus Christ there was only one, divine nature rather than two natures, divine and human, as asserted at the Council of Chalcedon in 451 . be involved in the suffering trajectories of life and humankind? (Küng 1970:624). According to Küng, this praxis question is the unique challenge to systematic and dogmatic thinking in the 20th century. Apathy cannot be used to defend an abstract and transcendent God-image (Küng 1970:626). God should be identified with human suffering. Thus, the emphasis on Theopaschie and the notion: Praxis of hope (Hedinger 1968:291).

Praxis thinking therefore implies a paradigm shift from theistic thinking to theopaschitic thinking. It is within this paradigm shift that both Jürgen Moltmann and Wolfhart Pannenberg advocated for a more open and cosmic understanding of God's involvement in the history of human suffering, than merely to stick to the static categories of abstract ontology (Pannenberg 1965:213). In this regard, the notion of a compassionate God, being-with, within the frailty and weakness of human suffering can play a decisive role in terms of an understanding of compassion as an expression of divine hospitality within the displacement crisis of human beings.

Feuerbach (1904:126-136) was often criticised as an enemy of Christian thinking. His thinking was labelled as a kind of atheistic attack on Christianity. However, when one studies his reflections on the essence of Christianity (das Wesen des Christentums), a different perspective arises. Very interestingly, Ludwig Feuerbach (see in Louw 2014, 2016a) explored a totally different avenue. Instead of the rational categories of the human mind, he turned in his critiques on Christian metaphysics to the passion categories of the human heart (the wisdom tradition).

Vulnerability and weakness are constituents of suffering and human experience; they are signs of passionate fulfilment and of a divine force in our being human (Feuerbach 1904:31). One can say that Feuerbach challenges the formal and zombie categories (Louw 2016a) of an institutionalised religion that projected a powerful imperium rather than a vulnerable ecclesiology.

According to Moltmann, Trinitarian thinking should reckon with the following paradigm shift: from authoritative domination to humane fellowship (being-with); from conquering to participation; from production to interrogation and empathetic listening. A new and different approach to Trinity should penetrate the arrogance of a positivistic mind; it should represent the dynamics of networking and should open up new avenues for human beings in their attempt to address issues of inhumane suffering and the destabilisation and destruction of the cosmos (Moltmann 1980:25).

Therefore, my hypothesis: omnipotence should be reframed by a pneumatology of compassionate being-with as an expression of the passio Dei within wisdom thinking 5.See the publication in 2009 by Keating and white with the title: Divine Impassibility and the Mystery of Human Suffering. 
(sapientia as the expression of the dynamics of divine presencing). Passion is not merely an emotional experience, but in terms of God's involvement in the history of humankind, an expression of sincere hospitality. Place and space in life should be viewed as spiritual entities. In this regard, a re-interpretation of the Rublev icon can contribute to the attempt to link in praxis thinking a wandering and compassionate God, to the dynamic happenstances of life as captured by infinite-speech rather than by Hellenistic, static and impassibility categories.

\section{Basic assumption and presupposition}

The basic assumption is: Static metaphysical and ontological categories cannot capture the dynamics of pity and compassion. Subjective and personal categories tend to psychologise God in terms of personal identity and selfhood. Metaphysical thinking does not represent the dynamics of Hebrew thinking with its emphasis on fellowship, communion and encircling embracement. Even if confessions still want to cling to the formulation of 'essentially one' (one in substance), but 'three different persons', a couple of intriguing questions still prevail: How does it link with wisdom thinking and its concrete focus on life issues? How could trinitarian thinking contribute to the enhancement of the humane quality of life?

My hunch is that instead of substantial and psychological categories, networking thinking should start to think and formulate divine presencing in terms of verbing-categories and not apply omni-categories that refer to abstract definition and substantial ontology. In this regard, the notion of perichoresis could become most appropriate in order to capture the mystery of a triad of operational divine engagement within the trajectories of life. The how of God's penetrating perichoresis is about an inviting hospitality wherein different perspectives play a supplementary role: The notion of 'Father' (perspective of procreator and provider), 'Son' (perspective of incarnation) and Holy Spirit (perspective of inhabitation). The challenge in theological reflection will be to move from definitions of God to 'infinitions of God'. Perhaps, this is the reason why Hebrew thinking did not want to apply personal or substance categories but think in terms of 'to-be-categories' (JHVH-categories) within the paradigmatic framework of promises regarding the 'faithfulness of God': The promise: I will be your God; I am the Exodus God. Therefore, the further promise: Wherever you are, I will be there - the accompanying, pitiful God (God-with-you). ${ }^{6}$

Thus, the following basic assumption: Trinity should be reframed in terms of to-be-categories in order to help the church to become a hospitable home for homeless migrating human beings and restless, violent outsiders, disturbing the comfort zones of content insiders.

6.5 ee the question of Moses in Exodus $2: 13$ and the answer (verse 14): "What is his name?'; 'I am who I am'. The verbing category and infinitive tense refer to a promise name?'; 'I am who I am'. The verbing category and infinitive tense refer to a promise
that God will always be there where they are, even in the desert because he is the moving and dynamic Exodus-God.

\section{Core problem}

The core problem of this article is the following: Is it possible to portray a Godhead wherein different infinitions (Father, Son and Holy Spirit) create an encircling space of fellowship that promotes and equips human beings to rediscover that the dynamics of God encompasses all spheres of life and infiltrates the hermeneutics of daily happenstances: the covenantal promise, namely, I will be there where you are? In this dynamic portrayal, how can a reinterpretation of the Rublev icon contribute to the paradigm switch from three persons (inter-trinitarian dynamics), to the playful aesthetics of divine perichoresis in life?; the trinitarian economics of hopefulness, meaningfulness and purposefulness - trinitarian teleology? Could such a perspective be linked to a pneumatological interpretation of the inhabitation of God, rather than the traditional incarnation of God?

The challenge will be how to move from substantial and personal categories to more fellowship categories; to move from distancing exclusive categories (divine detachment) to hospitable inclusive categories (divine attachment).

\section{The Rublev icon: A hospitable interplay of divine, sacrificial outreach to the stranger}

In my research on the link between aesthetics and an understanding of God, I have tried to reflect anew on the attempts of iconography, namely, how to portray God and to depict the Godhead in terms of aesthetic categories. The emphasis in my publication, Icons: Imaging the Unseen: On Beauty and Healing of Life, Body and Soul (2014), was on the question whether art and aesthetics can contribute to a new and fresh understanding of the passio Dei and the implications of a compassionate God, for example, on Christian anthropology, human sexuality and the gender debate, specifically on a re-interpretation on maleness.

The research project (2014) attended predominantly to an analysis of the Rublev icon on Trinity. Bunge (2007:79) pointed out that the very famous Russian icon by Rublev was used as a festival icon related to Pentecost (as result of, amongst other things, the legacy of Sergii of Radoneh). In the Russian tradition, Pentecost became the feast of the Holy Trinity as an indication of a time of the fulfilment of hope ; $^{7}$ a kind of pneumatological festivity of relationships. In this article, I want to explore the connection between Trinity, the aesthetics of festivity and pneumatology. The intention is to apply the research material to a theological hermeneutics of infinition, rather than definition.

Within the tradition of Christian spirituality, the narrative on the hospitality of Abraham (Gen. 18) was interpreted as an indication of a Divine event (Alpatov 1998:237-250). In the 
history of orthodox interpretation, the three angels acquire the status of the mysterium Trinitatis (Bunge 2007:51).

Rather than using words, definitions and formulations, traditional iconography turned to form and colour in order to shape the understanding of the godhead. In the icon, colour and composition were used to represent spiritual truth. In this attempt, ecclesial and dogmatic presuppositions indeed played a pivotal role. Icons therefore should establish the viewpoint of Russian orthodoxy. At the same time, it should connect the viewer with very plastic representations of divine interventions within the narratives of life events and human encounters. For example, Old Testament hospitality was transformed into a messianic Eucharist. The whole composition of the icon was then to enhance the mutual relationship and fellowship within the Trinity, framed against the background of the religious community and the setting in Palestine. The notion of being embraced by God's presence served as an appeal to the viewer to become part of this spiritual experience of being encircled by Divine presence (presencing) by means of liturgical worship (Louw 2014:169172). The whole impression of the icon is about embracement and encirclement.

In Andrei Rublev's icon (see Figure 1), the persons of the Holy Trinity are shown in the order in which they are confessed in the Credo. ${ }^{8}$ Even before the time of Rublev, the depictions of the Genesis 18 scenes were formally angelological from the beginning (Bunge 2007:51-54). ${ }^{9}$ The visitors in the narrative of Genesis 18 were understood as divine messengers or angels. Around 1500 gestures and postures of these three angels (completely identical) were used to describe the doctrine of the inter-Trinitarian relationship. The emphasis was on divine essence within the confessional truth of Trinity.

Important in the painting is composition, the emphasis on a circle and the colours applied to depict a communion rather than substance. The fact that all three figures are clothed in blue (the colour of heaven), and they do have the same faces, was a deliberate attempt to emphasise the notion of corresponding agreement and unison; it reflects the importance of monophysitism. However, the difference with abstract metaphysical thinking is that the icon links monophysitism with theopaschitism. The fact that all figures are designed in a circle with the chalice in the middle reveals the fact that a 'hospitable Godhead' is located to the notion of a tabernacle: the place of communion under the trees near Abraham's tent. God so to speak is becoming a moveable dwelling (tabernacle) in Israel.

The women present wisdom. The truth in the icon is the profession that God within the three persons is One in terms of a divine wisdom that, in pointing to the chalice, the unifying factor becomes the sacrifice and not the personhood

8.For more detail, see: Andrei Rublev's icon On Holy Trinity. Online: htpp:///www.holy transfiguration.org/library_en/lord_trinity_rublev.html. Accessed: 04/07/2011.

9.For a more detailed exposition and discussion on the interpretation of the Rublev icon, see Louw 2014:143, 146, 149, 169-172. See also the conclusion on the liturgical value of the icon: Truth as playfulness of a liturgy of life, pp. 172-173.

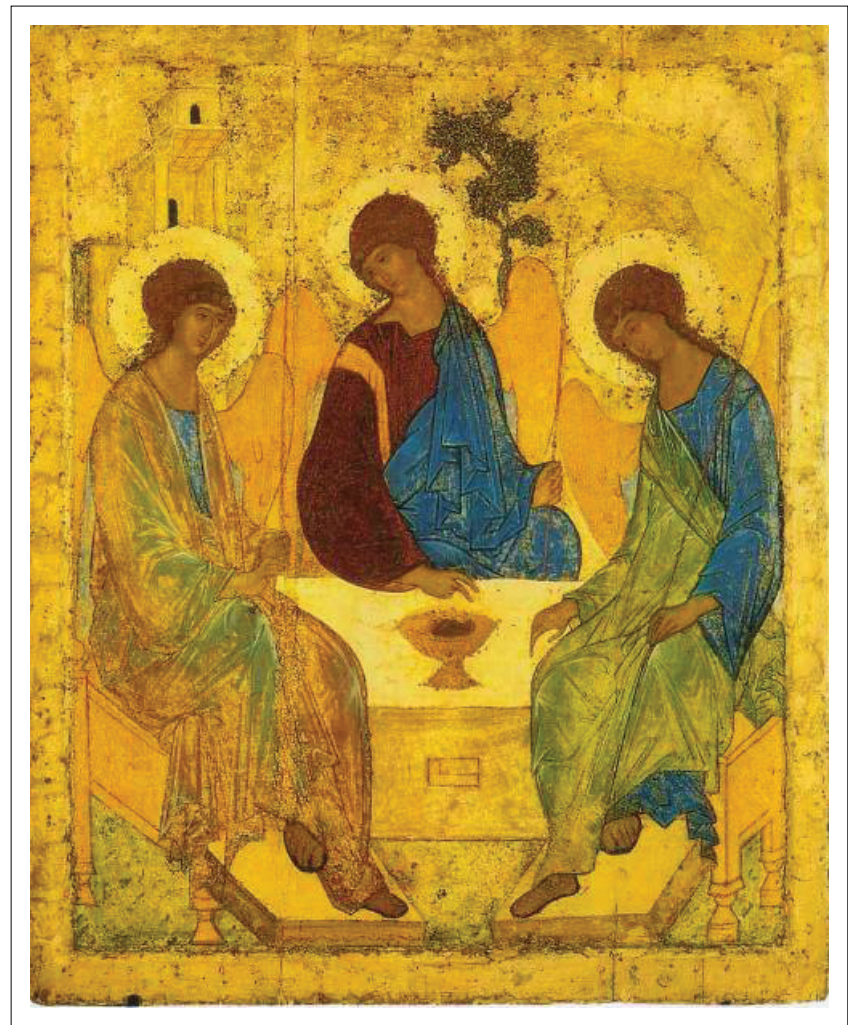

Source: Rublev, A., n.d., A Holy Transfiguration, viewed 04 July 2011, from http://www.holytransfiguration.org/library_en/lord_trinity_rublev.html

FIGURE 1: Icon of the Trinity believed to be created by the Russian painter Andre Rublev in the 15th century (Russian: Tроица, also called 'Rublev's Trinity').

of the three entities. This unity within the triune Godhead is framed in the icon by a mysticism that transcends rational analysis. Despite this mystic element, the communion and fellowship of the divine covenant proclaims the truth of hospitality and communion. The composition is determined by a circle because the intimate (peaceful) relationship with God encircles our being human.

It is believed that the first angel is the first person of the Trinity - God the Father; the second (middle) angel is God the Son; and the third angel is God the Holy Spirit. All three angels are blessing the chalice, in which lies a sacrificed calf, prepared for eating. All three angels have a staff in their hand as a symbol of their divine power as exercised in the shepherding perspective of divine caregiving. However, the emphasis is on the middle angel, even though the gaze of both the middle angel and the angel on the right are directed towards the authority (power) of the angel on the left (the Father). Rublev gave the angel in the middle the clothing of a kind of 'emperor mystique' (Louw 2014) that is characteristic of the authority of Christ. He added an unusual feature: The golden embroidered royal robe (the sewn-on stripe) (Bunge 2007: 87).

The first angel, shown on the left, is vested in a blue undergarment (just a small piece of it revealed), which depicts the divine celestial nature. The colour does not display enmity, but as connected to a light purple outer 
garment, the emphasis is on the royal dignity of this angel. This kind of dignity does not refer to abstraction, but to unique presence and place, namely, to an indwelling presence of the divine factor in life as expressed by the notions of 'home' or 'house'. Thus, the reason why behind the first angel, and above his head, towers a house (kind of tabernacle), the abode of Abraham, with a sacrificial altar in front of it (Louw 2014). This image of the abode has a symbolic meaning: The house signifies not merely the tabernacle narrative of Israel in the desert, but actually God's master plan for creation, and the fact that divine presence is an expression of divine hospitality. Fatherhood is a familial category and caregiving engagement with the trajectories of his intimate friend, namely, Abraham as representative of covenantal friendship. One can see how the other two angels have their heads inclined and eyes turned towards the first angel with great attention, as though conversing with him about the salvation of humankind and the promise to abide with human beings by means of communion and companionship. The icon, thus, does not become a static image but is embedded and portrayed within the Hebrew setting of the Genesis narrative. It even probes into the whole notion of pneumatology and its connection to Pentecost.

See, for example, the light blue undergarment and smokygreen outer garment of the third angel or messenger. Pale green plays a pivotal role in Russian spirituality. It was used to represent the liturgical colour of Pentecost. Green therefore functions as a symbol of new life; the Spirit as the Giver of Life (Bunge 2007:97).

The following components in the icon are important for a reinterpretation of Trinity:

- The composition, namely, Trinity as an encircling event focussed around the chalice: The establishment of reconciliation and forgiveness.

- Trinity functions within the dynamics of liturgy and not as an abstract dogmatic formulation.

- The paradigmatic framework is Abraham's hospitality: Inviting strangers (outsiders) as insiders and providing them with elements of life - bread and wine.

- The intersection between eternity (blue) and earth (green) and the connection to the life-bringing presence of the Spirit.

- The establishment of home (God as tabernacle) to accommodate human beings within the hospitality of an inclusive encirclement: Depicting ecclesial events as homecoming.

- The inter-trinitarian dynamics of encircling movement (relationality) rather than the emphasis on substantial stability (the impassibility Dei) - the dazzling going around of perichoresis and divine playfulness.

- The unifying factor is not the personality and substance of the three figures but the narrative of Abraham inviting three strangers into his home: hospitality as a factor of trinitarian interconnectedness.

Because of the focus on the chalice, the gaze of the three figures is captured by this wine cup used in the Christian
Eucharist, and, thus, the fact that the justification establishes a divine unity promoting and enriching the quality of human life - the economic dimension of an inter-trinitarian dynamics. While the middle figure looks at the Father (left), the Father reveals the intention of encircling embracement by focussing on the centrality of the salvation and reconciliation. The figure to the right points to this centrality so that pneumatology becomes the exposition of Christology within the dynamics of relational encircling and compassionate embracement. In fact, all three figures are pointing to the event of vicarious suffering as explication of trinitarian interaction (fellowship/koinonia) and compassionate beingwith. Compassion, thus, demarcates life. Divine communion links heaven and earth into a playful event of beautification (significance and destiny of life).

\section{The compassionate playfulness of divine encirclement (perichoresis): Homing in on the homeless stranger and outsider ${ }^{10}$}

The fact that divine engagement with life should not be expressed in static categories, but in dynamic being categories, is aptly described with the notion of perichoresis. Perichoresis refers to a kind of divine playfulness as an expression of immense joy and rotating communion. It is derived from two Greek words, peri, which means 'around', and chorein, which means 'to give way' or 'to make room'

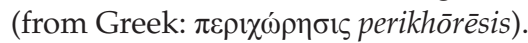

Perichoresis helps to understand that God's involvement with life and engagement within the trajectories of different happenstances cannot be expressed by abstract categories but should be portrayed by categories of space, place and encounter. Within God's covenantal embracement, human beings are encircled by divine events of ongoing 'hospitable sharing'. The fact is that within the event of hospitable embracement, human beings are encircled within compassionate encounters. God is therefore making room for human beings and their attempts to come to grips with frailty, weakness and suffering. As De Boer (1989:10) pointed out: This kind of encircling dynamics cannot become compartmentalised (De Boer 1989:10); it displays inclusive communication (De Boer 1976:79) and should be captured not by static categories but by means of an infinitive tense: a divine to be.

As a term, perichoresis expresses intimacy and reciprocity. The implication is that divinity cannot be expressed by enmity. It should rather be expressed in terms of the systemic, relational networking of human encounters.

Encounter means to make room and space, to influence; it indicates a kind of mutual intersection or interpenetration to reveal the life-giving impact of intimate relationship

10. For a discussion on the link and interplay between a theology of homecoming and the meaning of ta splanchna, see Louw (2017b). On the implication for a hermeneutics of the divine, compassionate being-with the other, the stranger, the outsider, see also Louw (2017b, 2017c). 
(communion) - hospitable outreach (diakonia) and compassionate being-with (paraclesis). In this sense, one can conclude that divine perichoresis is about the playful event of encounters wherein both God and human start to face one another, but, at the same time, become a kind of countenance to other human beings in their quest for dignity, justice and caregiving. Within the countenance of human encounters, perichoresis is making room for 'the other' - a kind of fellowship: Homing in on homeless human beings.

To 'face' one another is in terms of Levinas's thinking, an act of restorative justice, kindness and fairness. It describes a mode of facial disposition; countenance ${ }^{11}$ as relational encounter; and countenance as the opening up of one's being-there for the other. This kind of fellowship inhabits traces of divine presencing and caregiving. It acknowledges the other (especially the displaced stranger) by means of hospitable embracement. With reference to Levinas understanding, fellowship is to become aware of a metaphysical trace - the peculiar trace of the Other. The challenge is not to try and track the footprints, ${ }^{12}$ because in themselves they are not signs. One should rather reach out to all the Others that reside in the footprint of illeity (Levinas $1972)^{13}$. For Levinas, the challenge in fellowship is to understand the social-ethical entanglements. One should understand them from the perspective of the one-for-the-other (l'un pour l'autre). One could, thus, say that perichoresis as anexpression of joyful involvement and encircling, compassionate encounters, is about meeting all others where they are in terms of their daily predicaments.

Countenance in terms of encountering terminology within the confines of Christian theology and theopascitic thinking should be linked to the biblical concepts of promissio (promise), epangelia (gospel - good news), eschaton (not-yet of the future), parrhesia (boldness of speech and being), $t a$ splanchna (bowel categories referring to intestines), $r h m$ (pity) and hnn (grace). The praxis of hope and caregiving is therefore established by the passio Dei, the compassion of the suffering Christ - sincerity and the seriousness of God's compassion and faithfulness (esplanchnizomai) (Gärtner 1978). When linked to perichoresis ${ }^{14}$ and countenance, pastoral compassion refers to modality (Ott 1972:127) - to the how of God's being-with rather than to substantial abstraction of a divine definition.

11. By 'face' Levinas means the human face (or in French, visage) but not thought of or experienced as a physical or aesthetic object. Rather, the first, usual, unreflective or experienced as a physical or aesthetic object. Rather, the first, usual, unreflective
encounter with the face is as the living presence of another person and, therefore, encounter with the face is as the living presence
as something experienced socially and ethically.

12. Although the terms 'footprint' and 'trace' are more or less the same, 'trace' refers more to the general concept of a mark left behind; footprint refers more specifically to the meaningful contour (signification) and character of the mark.

13.IIle is the Latin form for the third person. Ille is a form of addressing the presence of transcendence by means of traces. Because God is transcendent, already
ahead and only leaves traces. Illeity refers to transcendence as presencing: He is there. He is there as trace, is about testifying that the infinite pass through the finite.

14. Literally from the Greek perichoreū $=$ to dance around. Furthermore, it is used in theology to describe the mutual exchange between divine presence and human existential reality; the ability to penetrate without losing its unique identity, as well as a metaphor for the description of the mystical, Trinitarian unity and diversity in the Godhead. See also Louw 2016.
When applied to pneumatology, perichoresis displays an inhabitational theology as expressed in terms of an interpenetrating pneumatology; the indwelling presencing of God through the Spirit (pneumatology) (inhabitatio Spiritus Sancti); perichoresis as a playful pneumatological event describing a kind of 'osmotic theology' (Van Ruler in Rebel 1981:85). Translated into categories of pity, caring and embracing grace, divine engagement and perichoresis refer to the moving, inner grace of God's compassionate sufferingwith. Thus, the argument that bowel categories express in a more profound and convincing mode, God's kindness and grace. 'The oldest form of the verb is splanchneu, eat the entrails, prophesy from the entrails' (Esser 1976:599).

This mode of bowel thinking about God has deep roots in Old Testament thinking. For example, in Deuteronomy 10:17, the power of God, and his transcendent splendid glory, becomes closely linked to his compassionate engagement with the dehumanising events of life. God's omnipotence is described not in abstract omni-categories, but in terms of justice and caring categories. God is the Lord of lords and the God of gods because of the fact that he shows no partiality and accepts no bribes. His countenance is described as follows: 'He defends the cause of the fatherless and the widow, and loves the alien, giving him food and clothing' (Dt 10:18; New International Version).

The point in these texts is that if it is true that praxis refers inter alia to intentionality and teleology, splanchnizomai reveals the very character of God within the messianic involvement and engagement with human suffering - a being-with (Hall 1993). The theology of the entrails reflects God's being quality (the how question) - it describes a kind of 'verbing event' (Louw 2017a).

\section{God as a 'verbing event': The infiniscience of the passio Dei}

Although Karl Barth (1959) was very hesitant to give human beings an active place in the events of salvation, he even calls 'religion' a kind of sinful surrogate (degeneration of the covenant of grace) with the danger of confusion and turmoil (KD IV/1 1953:537-538); nevertheless, he emphasises the notion of God-with-us. The latter is describing the being of God in its activity. God-with-us is not a kind of cause and abstract proprium for theoretical or empirical research (a kind of object for reflection); it does not describe a fixed condition a priori. God-with-us is essentially an event (ein Ereignis). The notion of God-with-us is essentially a description of God's being and life as a 'verbing event' (my interpretation) (KD IV/1 1953:4).

Undoubtedly, it is still difficult for systematic theology to ignore static categories that try to maintain substantial categories defending God's all-powerful status. Albeit, theologians already started in the second half of the previous century to link more and more power categories with God's passion, grace and pity (Moltmann 1972). 
Both Barth and Schleiermacher took as basic point of reference the notion of God's sovereign power, the notion of an all powering God (schaffende Allmacht). For Barth, the notion of God's righteousness is a key factor (Barth KD $1 \mathrm{~V} / 1$ 1953:282) in an understanding of the omnipotence of God. For Schleiermacher, the founding factor in a feeling of dependency (schlechthinniges Abhängigskeitsgefühl) is also an all-powerful divine factor (göttliche Allmacht) (Schleiermacher 1980:2014). Omnipotence functions as a causality that feeds the feeling of dependency. However, in both cases, omnipotence is determined by grace, pity and compassion. Also, Barth links power to the compassion of God (KD 1V/1 1953:84). The nerve and the very fibre of the connection between God and human beings is the passio Dei - the history of salvation as the history of passion (Heilsgeschichte ist wesentlich Passionsgeschichte) (KD 1V/1 1953:183). In this respect, Schleiermacher also links the notion of God's righteousness (Die Gerechtigkeit Gottes) (1980 Teilband 1:348) to the notion of the compassion of God (göttlichen Barmherzigkeit) (1980; Teilband 1: 356-357).

The point in our argument is that Schleiermacher's connection between our human disposition and sheer feeling of dependency and God's being with us, as well as in the case of Barth (God's being with us as an event of his presencing amongst us), are attempts to translate the divine factor into categories that link life events and the quality of life to compassionate lifestyles informed by the theological paradigm of the passio Dei. Habitus should then become a mode of living (compassionate lifestyle) that transforms violent and inhumane lifestyles into acts of meaningful and significant outreach to people suffering from inhumane acts of exploitation in civil society. In this regard, the re-interpretation of Trinity in terms of encircling hospitality of the Rublev icon can help revive a spirituality of sacrificial sharing and hospitable engagements. Religion, thus, becomes the social dynamics of a lived religion (Schleiermacher).

The advantage of the notion of 'lived religion', namely, the shift from abstract metaphysical and substantial categories into existential and experiential categories, is that theory formation should start to think more along the lines of dynamic happenstances (the infinition of to be) than in terms of life fixed definitions (the definition of essence). 'Thing' or 'substance' is about complex 'infinitives' rather than logical 'definitives' (Nilson 2007). Theory in science has then to deal with flux and an infinitive mode of knowing.

'The verbing of God' in terms of an infinitive mode can be described as a kind of practical theological gerund, a present participle. ${ }^{15}$ With the concept 'verbing of God' is not meant a

15. Used (a word that is not conventionally used as a verb, typically a noun) as a verb. Any English noun can be verbed, but some are more resistant than others. Verbing results in verbation. Although in a sense it is the inverse of a gerund, a word that has been verbed can actually be turned back into a noun as a gerund. Verbing means: The act of turning a noun into a verb. Hence, verbing is the gerund form of the verbed noun 'verb'. Verbing: http://www.urbandictionary.com/define. php?term=verbing. Accessed13/08/2017. Collins English Dictionary - Complete \& Unabridged 2012 Digital Edition (c) William Collins Sons \& Co. Ltd. 1979, 1986 (C) HarperCollins Publishers 1998, 2000, 2003, 2005, 2006, 2007, 2009, 2012. See also Miller-McLemore 2012:8. kind of relativism, but a mode of being (Sosein) and presencing activity. ${ }^{16}$ It indicates what Berkhof (1973:15) calls a living cooperative activity; God not as a static, immutable Being, but as a saving action of redemption and liberation within the world of phenomena. However, God in his faithfulness (factor of differentiation) demonstrates a kind of 'amen' (ämen = firmness) (Berkhof 1973:17), despite the discontinuity of human experiences.

Verbing points to relationality and encounter (Berkhof 1973:31-35); it describes compassionate being-with (Davies 2001:252; Hall 1993). It could be related to the fact that faith and hope is about a way of life $\mathrm{e}^{17}$ and not about an abstract, static definition of an immutable God.

\section{Conclusion: Trinitarian dynamics - On becoming a caring and hospitable community}

To conclude, inter-Trinitarian perichoresis is not the expression of a substantial pronoun, but the display of a verbing infinitive: Fatherly faithfulness, passionate Sonship and spirit-based fruitio beatifica. Trinitarian perichoresis does not describe a static and abstract definition of God, but in terms of the dynamics of the Rublev icon with its focus on a hospitable presence and divine encircling wherein the passion of the chalice (offering and mediatorial suffering) displays the sustainability of compassionate being-with, embracing communion and caregiving. The sustainable and ongoing infinitive tense as captured by the covenantal formula: The God of Abraham, Isaac and Jacob, describes the triad of a verbing God; it displays his mercy and pity by means of the sustainability of fulfilled promises, steadfast faithfulness and compassionate being-with (Louw 2016b).

The formula (God of Abraham, Isaac and Jacob as an indication of ongoing, steadfast, sustainable faithfulness) challenges the church to become an inclusive caring community within the public space of life: Homing in on the homeless. Trinity is actually about establishing human dignity (humanitas) by means of a triadic promissiology of hospitable, divine caring: the God of Abraham, Isaac and Jacob who promised to be always the God of the estranged and the displaced other (Levinas: the perspective of the onefor-the-other - l'un pour l'autre).

16.In fact, the concept 'God' in the Old Testament refers to the in finitive of a verb and not to a metaphysical substance or immutable principle. In the case of the naming
of God, the concept Jahvē, derived from the verb hih (Hebrew), indicates a vivid of God, the concept Jahvē, derived from the verb hih (Heb
promise that Jahvē will always be there where humans are.

17.The way of life is about a designation for conduct of life. In this regard, peripateō is used in a figurative sense as a description of a qualitative approach to life - an indication that one should conduct one's way of life in the paths of justice indicated by God. 'It obtains an outstanding significance as a term for denoting way of life; the nature and the manner of the way of life make it clear as to what governs man in his being and acting' (Ebel 1978b:944). In the New Testament, anastrepho describes a way of life as new communion in Christ - to turn away from a previous describes a way of life of of way of life to $3: 16)$, which determines and stamps the different lifestyle of Christian conduct ellowship with God then means to '...translate knowledge into practice' (Ebe 978a:934). 'To the Israelites, as to the oriental in general, the sheer vitality, concreteness and diversity of life were a course of the utmost delight (1 Ki 3:11; $\mathrm{Pr}$ 3:16; Job 2:4) - life synonymous with health, well-being and success (MI 2:5; Pr 2:19; Ps 56:13; Eccl 9:9)' (Link 1976:478). 
The unifying factor in trinitarian thinking should not be the personality and substance of three persons in the Godhead but, in terms of the Rublev icon, the biblical account on the narrative of Abraham inviting three strangers into his home: Hospitality as factor of trinitarian interconnectedness and expression of compassion.

In terms of the infiniscience of God, Trinity should represent and display (1) the verbing infinitive of a faithful Father; (2) the verbing infinitive of a suffering Son - vicarious suffering (mediatory); and (3) the verbing infinitive of the inhabitational Spirit: pneumatological presencing (Louw 2017c).

Former Archbishop Desmond Tutu puts the following challenge on the table of theological reflection (Tutu 2004):

We were involved in the struggle because we believed we would evolve a new kind of society. A caring compassionate society. At the moment many, too many, of our people live in gruelling demeaning, dehumanising poverty. We are sitting on a powder keg. We really must work like mad to eradicate poverty. (p. 33)

Compassion gives meaning to life. Dostoyevsky concurred with the assumption that without compassion life becomes an unbearable toil. Compassion makes life bearable. 'Compassion would teach even Rogozhin, give a meaning to his life. Compassion was the chief and, perhaps, the only law of human existence' (Dostoyevsky 1973:263). Compassion is the cornerstone of all modes of ecclesial fellowship; it displays a trinitarian dynamics of hospitable koinonia and diakonia.

\section{Acknowledgements Competing interests}

The author declares that they have no financial or personal relationships which may have inappropriately influenced them in writing this article.

\section{Author's contributions}

D.J.L. is the sole contributor to this research article.

\section{Ethical considerations}

This article followed all ethical standards for a research without direct contact with human or animal subjects.

\section{Funding information}

This research received no specific grant from any funding agency in the public, commercial, or not-for-profit sectors.

\section{Data availability statement}

Data sharing is not applicable to this article as no new data were created or analysed in this study.

\section{Disclaimer}

The views and opinions expressed in this article are those of the author and do not necessarily reflect the official policy or position of any affiliated agency of the author.

\section{References}

Alpatov, V.M., 1998, 'Die Russischen Ikonen', in K. Weitzman et al. (ed.), Die Ikonenen pp. 237-250, Herder Verlag, Freiburg im Breisgau.

Barth, K., 1953, 'Die Lehre der Versöhnung', in Die Kirchliche Dogmatik (KD), Vierter Band, Erster Teil (IV/1), Evangelischer Verlag AG, Zollikon-Zürich.

Barth, K., 1959, 'Die Lehre der Versöhnung', in Die Kirchliche Dogmatik (KD), Vierter Band, Dritter Teil (IV/3), Evangelischer Verlag AG, Zollikon-Zürich.

Berkhof, H., 1973, Christelijk geloof, Callenbach, Nijkerk.

Bunge, G., 2007, The Rublev Trinity. The Icon of the Trinity by the Monk-Painter Andrei Rublev, St Vladimir's Seminary Press, New York.

Davies, O., 2001, A theology of compassion. Metaphysics of difference and the renewal of tradition, William B. Eerdmans Publishing Company, Grand Rapids, MI.

De Boer, T., 1976, Tussen filosofie en profetie - De wijsbegeerte van Emmanuel Levinas, Ambo, Baarn.

De Boer, T., 1989, De God van de filosofen en de God van Pascal - Op het grensgebied van filosofie en theologie, Meinema, Gravenhage.

Dostoyevsky, F., 1973, The Idiot, Penguin Books, Harmondsworth.

Ebel, G., 1978a, 'Anastrephō', in C. Brown (ed.), The New International Dictionary of New Testament Theology, pp. 933-935, vol. 3, The Paternoster Press, Exeter.

Ebel, G., 1978b, 'Hodos', in C. Brown (ed.), The New International Dictionary of New Testament Theology, vol. 3, pp. 935-943, The Paternoster Press, Exeter.

Esser, H.-H., 1976, ,Splanchna', in C. Brown (ed.), Dictionary of New Testament Theology, vol. 2, Paternoster Press, Exeter.

Feuerbach, L., 1904, Das Wesen des Christentums, Verlag Philipp Reclam, Leipzig.

Gärtner, B., 1978, 'Suffer (paschō)', in C. Brown (ed.), Dictionary of New Testament theology, vol. 3, pp. 719-725, Paternoster, Exeter.

Hall, D.J., 1993, Professing the faith. Christian Theology in a North American Context, Fortress Press, Minneapolis, MN.

Hedinger, U., 1968, Hoffnung zwischen Kreuz und Reich. Studien und Meditation über die Christliche Hoffnung, Basler Studien zur historischen und systematische Theologie, EVZ Verlag, Zürich.

Kempen, M., 2015, 'Coaching als abduktiver Prozess vor dem bleibenden Geheimnis. Die Theorie U aus pastoralpsychologischer Perspektive', Doctoral dissertation, Philosophisch - Theologische Hochschule, Sankt Georgen, Institut fur Pastoralpsychologie und Spiritualität, Frankfurt am Main.

Keating, J.F. \& White, T.J., 2009, Divine impassibility and the mystery of human suffering, Eerdmans, Grand Rapids, MI.

Küng, H., 1970, Menschwerdung Gottes, Herder, Freiburg im Breisgau.

Levinas, E., 1972, Humanisme de l'autre homme, Fata Morgana, Montpellier.

Link, H.-G., 1976, 'Life (bios)', in C. Brown (ed.), The New International Dictionary of New Testament Theology, vol. 2, pp. 474-483, The Paternoster Press, Exeter.

Louw, D.J., 2014, Icons. Imaging the unseen. On beauty and healing of life, body and soul, Sun Media, Stellenbosch.

Louw, D.J., 2016a, Wholeness in hope care. On nurturing the beauty of the human soul in spiritual healing, Pastoral care and spiritual healing, vol. 3, D. Louw, U. Elsdörfer \& S. van der Watt (eds.), Lit Verlag, Wien.

Louw, D.J., 2016b, 'Theological complexity and the blindness of theory Barbarism in a pastoral Hermenutics: Towards the "infiniscience of god" in processes of hoping and faithful knowing (Epistemology)', Scriptura 115(1), 1-19. https://doi. org/10.7833/115-0-1289

Louw, D.J., 2017a, 'Ekhaya: Human displacement and the yearning for familial homecoming. From Throne (Cathedra) to Home (Oikos) in a grassroots ecclesiology of place and space: Fides Quaerens Domum et Locum [Faith seeking home and space]', HTS Teologiese Studies Theological Studies 73(4). https://doi. org/10.4102/hts.v73i4.4484

Louw, D.J., 2017b, 'Practical theology as life science: Fides Quaerens Vivendi and its connection to Hebrew thinking (Hālak)', In die Skriflig/In Luce Verbi 51(1), a2239. https://doi.org/10.4102/ids.v51i1.2239

Louw, D.J., 2017c, 'Black-White polarisation in \#MustFall campaigns. Towards a practical theological diagnostics of "peaceful coexistence"”, In die Skriflig/In Luce Verbi 51(1), a2220. https://doi.org/10.4102/ids.v51i1.2220'

Miller-McLemore, B.J., 2012, 'Introduction. The contributions of practical theology', in B.J. Miller-McLemore (ed.), The Wiley-Blackwell companion to practical theology, pp. 1-20, John Wiley \& Sons, Malden, MA.

Moltmann, J., 1972, Der gekreuzigte Gott, Kaiser, München.

Moltmann, J., 1980, Trinität und Reich Gottes. Zur Gotteslehre, Kaiser Verlag, München.

Nilson, F., 2007, 'Towards a dialectic complexity framework: Philosophical reflections', K.A. Richardson \& P. Cilliers (eds.), Explorations in complexity thinking: Preproceedings of the 3rd International Workshop on Complexity and Philosophy, pp. 236-249, ISCE Publishing, Mansfield.

Ott, H., 1972, Die Antwort des Glaubens, Kreuz, Berlin.

Pannenberg, W., 1965, Der Gott der Hofnung. Ernst Bloch zu ehren, Suhrkamp Verlag, Frankfurt am Main. 
Psalter, H., 1959, Doctrinal standards and liturgy of the Christian reformed church Publication Committee of the Christian Reformed Church, Inc. Publishers., Grand Rapids, MI.

Rebel, J.J., 1981, Pastoraat in pneumatologisch perspektief: Een theologische verantwoording vanuit het denken van A van Ruler, Kok, Kampen.

Rublev, A., n.d., A Holy Transfiguration, viewed 04 July 2011, from http://www.holytransfiguration.org/library_en/lord_trinity_rublev.html.
Schleiermacher, F.D.E., 1980, Der Christliche Glaube nach der Grundsätzen der evangelischen Kirche im Zusammenhange dargestellt (1821/22), Teilband 1, Walter de Gruyter, Berlin

Stace, W.T., 1960, A critical History of Greek Philosophy, Macmillan \& Co., London.

Tutu, D., 2004, Nelson Mandela annual lecture, viewed 20 September 2014, from http://nelsonmendela.org/uploads/files/NMF_Lecture_Book_small.pd. 